\title{
The Characterization and Localization of the Glutamate Receptor Subunit GluR1 in the Rat Brain
}

\author{
Scott W. Rogers, ${ }^{1}$ Thomas E. Hughes, ${ }^{3}$ Michael Hollmann, ${ }^{1}$ Gregory P. Gasic, ${ }^{1,2}$ Evan S. Deneris, ${ }^{4}$ and Stephen \\ Heinemann' \\ 'Molecular Neurobiology Laboratory and ${ }^{2 H o w a r d ~ H u g h e s ~ M e d i c a l ~ I n s t i t u t e, ~ T h e ~ S a l k ~ I n s t i t u t e ~ f o r ~ B i o l o g i c a l ~ S t u d i e s, ~ L a ~}$ \\ Jolla, California 92037, ${ }^{3}$ Department of Neuroscience, University of California, San Diego, California 92093, and \\ ${ }^{4}$ Department of Neuroscience, Case Western Reserve University, Cleveland, Ohio 44106
}

The cloning of cDNAs that encode functional glutamate receptors makes it possible to produce antibodies that can be used as high-affinity probes for the localization and characterization of these receptors in the mammalian brain. We have made antibodies to different regions of the first cloned member of this family, GluR1, using bacterially overproduced antigen. On Western blots, these antisera detect glycoprotein(s) of $105 \mathrm{kDa}$ present in crude membranes of the hippocampus and cerebellum. The 105-kDa band is associated with postsynaptic densities, and it is observed in cultured cells upon transfection with the GluR1 cDNA. Although glutamate receptors are thought to be the most prevalent excitatory ligand-gated ion channel in the mammalian brain, immunohistochemistry reveals that the receptors recognized by these antisera are localized predominantly in neurons of the cerebellum and some structures of the limbic system, including the hippocampus, the central nucleus of the amygdala, and portions of the septum. This pattern of expression is, in general, consistent with the distribution of GluR1 mRNA as determined by in situ hybridization histochemistry. Our results suggest that glutamate excitatory circuits recognized by these antisera are predominantly found in regions of the limbic system that are reciprocally interconnected.

Glutamate-gated ion channels have been implicated in a wide variety of neuronal functions, including most of the excitatory synaptic transmission in the CNS, synaptic plasticity, and possibly the formation of memory (see Collingridge and Bliss, 1987; Stevens, 1989). Dysfunction of these receptors may play a role in the etiology of diseases such as Huntington's disease, epilepsy, ischemic-related damage, and dementia (for review, see Choi,

Received Dec. 21, 1990; revised Mar. 28, 1991; accepted Apr. 2, 1991.

We extend thanks to Kevin Cox for excellent technical assistance and to Wylie Vale and his colleagues for their generosity and patience while providing us with rat CNS material. This work was supported by the Fritz B. Burns Foundation, by NINCDS Grants NS28709-01 and NS1 1549 to S.H., by N.E.I. Grant EY0836201 to T.E.H., and by an American Federation for Aging Research grant to S.W.R. Additional funding was provided by postdoctoral fellowships from NIH to S.W.R. and from the Deutsche Forschungsgemeinschaft to M.H., by an HHMI postdoctoral fellowship to G.P.G., and by HHMI funding to Charles Stevens. We extend a special thanks to IIarvey J. Karten (funded by NINCDS Grant NS24560-04) for his continued assistance and support. We also thank the anonymous reviewers for their careful reading of the manuscript and their thoughtful suggestions.

Correspondence should be addressed to Scott W. Rogers, Molecular Ncurobiology Laboratory, The Salk Institute, P.O. Box 85800, San Diego, CA 92138.

Copyright (C) 1991 Society for Neuroscience $0270-6474 / 91 / 112713-12 \$ 03.00 / 0$
1988; Albin et al., 1989; Greenamyre and Young, 1989; McGeer, 1989; Olney, 1990). Therefore, determining the structure, function, and distribution of these receptors is of importance toward understanding the role of excitatory amino acid transmission in the CNS and the disease states to which they contribute.

Recently, a cDNA encoding a functional member of the glutamate receptor family called GluR-K1 was isolated from a rat brain cDNA library (Hollmann et al., 1989), and since this original finding, four closely related clones (Bettler et al., 1990; Boulter et al., 1990b; Keinanen et al., 1990; Hollmann et al., 1991) and splice variants of these clones (Bettler et al., 1990; Sommer et al., 1990) have been reported. The nomenclature for these subunits has been revised, and they are now referred to as GluR1 through GluR5, in the order of their discovery. Analysis of the deduced amino acid sequences from members of this receptor family reveals proteins of approximately 900 residues that have a predicted molecular weight of about 100 $\mathrm{kDa}$. Additional analyses also predicted the presence of a leader sequence, indicating the $\mathrm{N}$-terminus to be extracellular, and four transmembrane domains in the $3+1$ configuration characteristic of other ligand-gated ion channels such as nicotinic ACh, GABA, and glycine receptors (see Claudio et al., 1983; Barnard et al., 1987; Deneris et al., 1988a). The pharmacology of these receptor subunits when expressed in Xenopus oocytes or transiently transfected cells suggests that they are of the "non-NMDA" type.

The cloning of functional members of the glutamate receptor family (Hollmann et al., 1989) provides the first opportunity to develop specific probes against these receptors that can be used to investigate their structure, regulation, and distribution. Here, we report the results of studies using antibodies, made to bacterially overproduced portions of GluR1, to begin the characterization and to analyze the distribution of the proteins encoded by this important family of genes in the rat brain.

\section{Materials and Methods}

Bacterial overproduction and antibody production. The trp $\mathrm{E}$ bacterial overexpression system (Dieckmann and Tzagoloff, 1985) was used to obtain antigen for injection into rabbits. A Hinc II-BamH I fragment of the GluR1 cDNA encoding a portion of the putative extracellular domain (residues 185-449) was subcloned into the $\mathrm{pATH} 1$ vector and used to transform $E$. coli strain HB101. Similarly, a Bgl II-Xho I fragment containing the coding region for a portion of the putative cytoplasmic domain through the carboxy terminus (residues 658-889) was subcloned into the pATH 3 vector, which was maintained as above. Induction, collection, and enrichment of fusion proteins was as de- 
scribed by Dieckmann and Tzagoloff (1985). These fusion proteins were size fractionated using SDS-PAGE and visualized by soaking the gel in ice-cold $0.25 \mathrm{M} \mathrm{KCl}$ for $30 \mathrm{~min}$. A portion of the gel containing approximately $400 \mu \mathrm{g}$ of fusion protein was removed, macerated, emulsified in Freund's complete adjuvant (Gibco/Bethesda Research Labs, Grand Island, NY) and was injected subcutaneously into young New Zealand white rabbits. Four weeks later, the rabbits were boosted with antigen in Freund's incomplete adjuvant. Two weeks later, serum was collected by ear bleed. Antibodies raised to trpE were removed from the serum by batch adsorption against the crude insoluble portion of bacteria expressing the unfused $\operatorname{tr} p \mathrm{E}$ protein. The adsorbed immune serum retained little or no observable reactivity toward fusion proteins other than the one used for immunization as determined by Western blot analysis (not shown).

Preparation of rat brain membrane fractions. Young Sprague-Dawley rats were killed, and the brains were immediately removed from the cranium and stored in ice-cold dissection buffer [50 mm Tris-acetate (TA), $\mathrm{pH} 7.4,10 \%$ sucrose, $5 \mathrm{~mm}$ EDTA] containing a freshly added protease inhibitor cocktail of $1 \mathrm{~mm}$ phenylmethylsulfonyl fluoride, 20 $\mu \mathrm{g} / \mathrm{ml}$ aprotinin, $2.5 \mu \mathrm{g} / \mathrm{ml}$ pepstatin, $20 \mu \mathrm{g} / \mathrm{ml}$ benzamidine, and 20 $\mu \mathrm{g} / \mathrm{ml}$ iodoacetamide prior to dissection. The brain was partitioned into the cerebellum, the hippocampus, the forebrain (consisting primarily of the cortex and some underlying basal ganglia), the rostral brainstem (consisting of the diencephalon and midbrain), and the caudal brainstem (consisting of the pons and medulla oblongata).

To prepare synaptic plasma membranes (SPMs; Jones and Matus, 1974), each tissue was supplemented with 9 vol of dissection buffer and was homogenized in a motor-driven 50-ml Potter-Elvehjem homogenizer fit with a Teflon pestle. All procedures were conducted in a cold room at $4^{\circ} \mathrm{C}$ with precooled solutions. After 20 strokes with the piston, the homogenate was centrifuged at $800 \times g$ for $20 \mathrm{~min}$. The supernatant was removed and homogenized again, and centrifugation was repeated. The supernatant was rehomogenized and centrifuged at $16,000 \times g$ for $30 \mathrm{~min}$, and this procedure was repeated once. This pellet was resuspended in $20 \mathrm{~mm}$ HEPES buffer ( $\mathrm{pH} 7.4$ ) and centrifuged at $16,000 \times$ $g$, and the pellet was resuspended in this buffer, rehomogenized, and stored in $200-\mu \mathrm{l}$ aliquots at $70^{\circ} \mathrm{C}$. Crude membrancs werc poolcd, resuspended in $5 \mathrm{vol}$ (of the original tissue wet weight) of lysis buffer ( $5 \mathrm{~mm}$ Tris-acetate, $\mathrm{pH} 8.1$, and freshly added protease inhibitors as above), and gently homogenized with three strokes of the piston. The homogenate was left for $45 \mathrm{~min}$ to lyse synaptosomes and vesicles, and homogenization was repeated with 10 strokes of the piston. The homogenate was supplemented to yield a $34 \%(w / w)$ sucrose suspension in $50 \mathrm{~mm}$ Tris-acetate (TA), $\mathrm{pH} \mathrm{7.4,} \mathrm{and} \mathrm{was} \mathrm{used} \mathrm{as} \mathrm{the} \mathrm{bottom} \mathrm{of} \mathrm{a}$ three-step gradient that was carefully overlayed with equal volume of $28.5 \%(\mathrm{w} / \mathrm{w})$ sucrose/TA and a one-third volume of $10 \%$ sucrose $(\mathrm{w} /$ w)/TA. The gradients were centrifuged at $60,000 \times g$ for $2 \mathrm{hr}$. The broad band at the $28.5 \% / 34 \%$ sucrose interface, consisting primarily of synaptic plasma membranes, was collected, pooled, diluted with TA to $10 \%$ sucrose, and pelleted by centrifugation at $48,000 \times g$ for 30 minutes. These pellets were stored at $-70^{\circ} \mathrm{C}$.

Postsynaptic densities were prepared as follows: Synaptic plasma membranes $(1.4 \mathrm{mg}$ ) were resuspended in $3 \mathrm{ml} \mathrm{TA}$, homogenized in a Dounce homogenizer, mixed with an equal volume of $3 \%$ Triton X-100, stirred at $4^{\circ} \mathrm{C}$ for $30 \mathrm{~min}$, and then layered on $30 \mathrm{ml}$ of $28.5 \%(\mathrm{w} / \mathrm{w})$ sucrose/TA, followed by centrifugation at $105,000 \times g$ for $1 \mathrm{hr}$. The supernatant was saved, concentrated by Amicon centrifugation filtration, and dialyzed against TA, and aliquots were stored at $-70^{\circ} \mathrm{C}$. The pellet was resuspended in TA by pipetting and was pelleted again by centrifugation in a microfuge for $15 \mathrm{~min}$. This pellet, containing the postsynaptic densities (PSDs), was resuspended in TA, homogenized, aliquoted, and stored at $-70^{\circ} \mathrm{C}$.

Western blot analysis. Fractionated proteins were transferred overnight at $4^{\circ} \mathrm{C}$ to nitrocellulose (PH 79; Schleicher and Schuell, Keene, NH) using a Hoefer TE-65 tank transfer system containing freshly prepared transfer buffer ( $10 \mathrm{~mm}$ MOPS, $4 \mathrm{~mm}$ sodium acetate, $\mathrm{pH} 7.5$, $20 \%$ ethanol, and $0.1 \%$ SDS; Kidd et al., 1989). The blots were blocked with Blotto $5 \%$ Carnation nonfat dry milk in PBS and $0.01 \%$ sodium azide) for $45 \mathrm{~min}$ at room temperature, transferred to a plastic bag containing Blotto and rabbit antiserum at the appropriate dilutions, and rocked either $4 \mathrm{hr}$ at room temperature or overnight at $4^{\circ} \mathrm{C}$. The blots were then washed in Blotto, transferred to Blotto containing 1:1000 goat anti-rabbit alkaline phosphatase-coupled secondary antibody (Cappel, Malvern, PA) for $1 \mathrm{hr}$ at room temperature, washed with Blotto in Tris$\mathrm{HCl}(\mathrm{pH} 7.5)$, washed in developing buffer ( $50 \mathrm{~mm}$ sodium carbonate,
pH 9.5, 2 mm magnesium sulfate), and then developed in developing buffer containing $1 \mathrm{mg} / \mathrm{ml}$ nitroblue tetrazolium and $0.5 \mathrm{mg} / \mathrm{ml} 5$-bromo-4-chloro-3-indolyl phosphate. Development was stopped with PBS/1 mM EDTA.

Expression vectors and transfected cell lines. The complete cDNA encoding GluRI was shuttle cloned into the SV40 expression vector pECE (Ellis et al., 1986) to which the HSV-thymidine kinase gene (Hudziak et al., 1982) was added at the BamH1 site to create the vector $\mathrm{pECE} / \mathrm{TK}$. To place GluR 1 into pECE/TK, the EcoR I/Xho I fragment containing GluR 1 was subcloned into the plasmid pGEM -7Zf(+) (Promega, Madison, WI), which had been linearized in the polylinker by codigestion with EcoR I and Xho I. The GluR 1 cDNA was subsequently removed from the pGEM -7Zf( + -GluR 1 carrier plasmid by codigestion with Hind III/Xba I and subcloned into the pECE/TK plasmid, which was linearized in the polylinker by codigestion with the same restriction enzymes. Rat 2 cells (TK-, ATCC CRL 1764) were cultured in Dulbecco's modified Eagle's medium (DMEM) supplemented to 5\% with both fetal bovine serum and calf serum and containing penicillin-streptomycin (Gibco/Bethesda Research Labs, Grand Island, NY). Cells were subcultured at confluency by rinsing the monolayer with PBS, dislodging the cells by a brief treatment with trypsin/EDTA, washing with PBS, and returning the desired number of cells to a new culture dish. Cells were cultured in Falcon 100- or 150-mm culture dishes in a humidified atmosphere containing $5 \% \mathrm{CO}_{2}$ at $37^{\circ} \mathrm{C}$. To transfect cultured Rat 2 cells, $10 \mu \mathrm{g}$ of pECE/TK-GluR 1 was introduced into $1 \times 10^{6}$ cells using the calcium phosphate precipitation method (Wigler et al., 1978). Transfection proceeded for $14 \mathrm{hr}$ before removing the medium and washing the monolayer twice with PBS. Culture was continued for $48 \mathrm{hr}$, whereupon stably transfected cells were selected by supplementing DMEM with HAT (Gibco/Bethesda Research Labs, Grand Island, NY). At approximately the 2000 -cell stage, clones were removed by trypsinization and expanded in HAT containing DMEM. Northern blot analysis was done as described by Boulter et al. (1990a)

Crude membranes were prepared from transfected cells as follows: Cells were rinsed with an ice-cold solution of $250 \mathrm{~mm}$ sucrose and 1 mM EDTA containing protease inhibitors formulated above, scraped from the culture dish in the same solution with a rubber policeman, and transferred to a Dounce homogenizer on ice. The cell suspension $(\approx 2 \mathrm{ml})$ was subjected to $40-60$ brisk strokes of the piston, which routinely disrupted $90 \%$ of the cells as determined by phase-contrast microscopy. The homogenate was sedimented at $800 \times g$ for $15 \mathrm{~min}$ to remove nuclei and unbroken cells. The supernatant was then centrifuged at $50,000 \times g$ for $90 \mathrm{~min}$ to produce the crude membrane fraction. This pellet was resuspended in $50 \mathrm{~mm}$ Tris (pH 8.0) and again sedimented before dissolving it in Laemmli's sample buffer for subsequent Western blot analysis.

Deglycosylation. Deglycosylation reactions were done as follows: To $20 \mu \mathrm{l}$ of rat hippocampal crude membranes $(700 \mu \mathrm{g})$ were added $20 \mu \mathrm{l}$ distilled water, $40 \mu \mathrm{l}$ of $2 \times$ glycosidase buffer [ $50 \mu \mathrm{M}$ sodium phosphate (pH 6), 20 mM EDTA, 0.4\% SDS, 1\% 2-mercaptoethanol), and a freshly added protease inhibitor cocktail (as above) containing either no endoglycosidase, $20 \mathrm{U}$ endoglycosidase $\mathrm{H}$, or $0.2 \mathrm{U}$ N-glycosidase $\mathrm{F}$ (Boehringer Mannheim, Indianapolis, IN). These reactions were incubated for $4 \mathrm{hr}$ at $37^{\circ} \mathrm{C}$ and then stopped by adding $20 \mu \mathrm{l}$ of $5 \times$ Laemmli's sample buffer, mixing, and heating the sample to $100^{\circ} \mathrm{C}$ for $5 \mathrm{~min}$.

Immunohistochemistry. Immunohistochemistry was done essentially as described by Hughes et al. (1989). A total of 12 rats, 1-6 months old, were anesthetized with a lethal dose of sodium pentobarbital and perfused with $50 \mathrm{ml}$ saline followed by $500 \mathrm{ml} 4 \%$ paraformaldehyde in phosphate-buffered saline (PBS; pH 7.4, $0.1 \mathrm{~m}$ ). The brains were removed and postfixed for $2 \mathrm{hr}$, cryoprotected in 30\% sucrose/PBS, frozen, and cut into $30-\mu \mathrm{m}$-thick sections on a sliding microtome. The sections were washed in three changes of PBS, incubated for $1 \mathrm{hr}$ in a PBS solution of $2 \%$ normal goat serum and $0.1 \%$ Triton X-100, and incubated for $12 \mathrm{hr}$ at $4^{\circ} \mathrm{C}$ in either the preimmune or the immune sera diluted 1:2000 with PBS containing normal goat serum and $0.1 \%$ Triton $\mathrm{X}-100$. The tissue was then washed and incubated with biotinylated goat anti-rabbit IgG $(\mathrm{H}+\mathrm{L}$, diluted $\mathrm{I}: 200$; Vector Laboratories, Burlingame, CA) in PBS with $0.1 \%$ Triton X-100 for $1 \mathrm{hr}$, washed again, and reacted with the Vectastain $\mathrm{ABC}$ elite kit (Vector Laboratories, Burlingame, CA) to provide a peroxidase-reduced diaminobenzidine labeling. The sections were mounted on slides, dehydrated, cleared, and coverslipped.

In situ hybridization histochemistry. The distribution of GluR1 encoded message was done as follows: The Bluescript plasmid (see Holl- 
mann et al., 1989) containing the full-length GluR1 cDNA was linearized to prepare full-length ${ }^{35} \mathrm{~S}$-labeled antisense probes. Conditions for in situ hybridization histochemistry were as previously described by Deneris et al. (1988b) and E. Wada et al. (1989).

\section{Results}

\section{Antibodies to GluR1 identify a 105-kDa protein in the rat CNS}

To characterize the protein product recognized by antisera raised to GluR1, we produced antibodies to portions of the putative intracellular (residues 658-889) or extracellular (residues 185449) domains of the GluR 1 receptor protein (Fig. 1A) using the trpE bacterial expression system (Dieckmann and Tzagoloff, 1985). The cytoplasmic-domain fusion protein was injected subcutaneously into rabbits $\mathrm{C} 72$ and $\mathrm{C} 73$, and the extracellulardomain construct was injected into rabbits E10 and E11. The results for antisera $\mathrm{C} 73$ and $\mathrm{E} 11$ are shown because they produce particularly robust labeling. Because the amino acid sequences derived from the various cDNAs related to GluR1 exhibit substantial sequence identity (Hollmann et al., 1989, 1991; Bettler et al., 1990; Boulter et al., 1990b; Keinanen et al., 1990; Sommer et al., 1990), the antisera produced to GluR1 may also detect other closely related members of this gene family. Although the cytoplasmic domains are almost identical among cloned members of the glutamate receptor family, there are significant differences between sequences of cDNAs related to GluR1 in the extracellular domain against which antisera E10 and E11 were raised. To determine the specificity of these antisera to GluR1, we produced in bacteria the equivalent regions of the closely related GluR2 (nucleotides 906-1668; Boulter et al., 1990b), GluR3 (nucleotides 967-1597; Boulter et al., 1990b), and GluR5 (nucleotides 990-1889; Bettler et al., 1990). As shown in Figure $1 B$, antiserum E11 failed to react on Western blots with the equivalent portions of GluR2, GluR3, or GluR5. Identical results were obtained for antiserum E10 (not shown). This result indicates that immunoreactivity of E10 or E11 antisera toward other closely related members of the glutamate receptor family is not extensive.

We used the antibodies $\mathrm{C} 73$ and E11 to identify the immunoreactive species on Western blots and to determine the distribution of the reactive species in the rat brain. To do this, rat brain crude membranes were prepared from the rostral or caudal regions of the brainstem, the cerebellum, the forebrain, or the hippocampus (see Materials and Methods). Crude membranes $(500 \mu \mathrm{g})$ from each tissue were fractionated on $7.5 \%$ SDS-polyacrylamide gels and transferred to nitrocellulose filters, and the immunoreactivity was visualized with antiserum to GluR1 fusion proteins. Antisera raised against both the extracellular and the cytoplasmic regions of the GluR1 antigen recognize a 105$\mathrm{kDa}$ band (Fig. $2 A$ ), which is consistent with the molecular weight of about $100 \mathrm{kDa}$ predicted from the amino acid sequence encoded by GluR1. The $105-\mathrm{kDa}$ antigen is abundant in the hippocampus and cerebellum, and it is present at low levels in the forebrain and rostral brainstem. Immunoreactivity is not observed in the caudal brainstem or liver (not shown).

In addition to the 105-kDa protein, some antisera also detect 97-kDa and 170-kDa proteins (Fig. $2 B$ ). These proteins share

Figure 1. Portions of GluR1 produced in bacteria and reactivity of antiserum E11 to other closely related glutamate receptors. $A$, Schematic

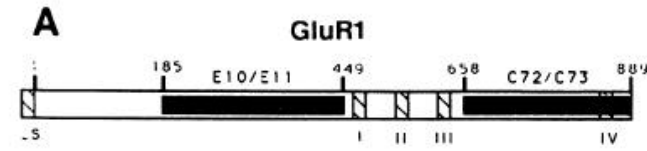

B Protein: trpE R1 R2 R3 R5 R1L

M.W. (kD) Coomassie Blue Stain
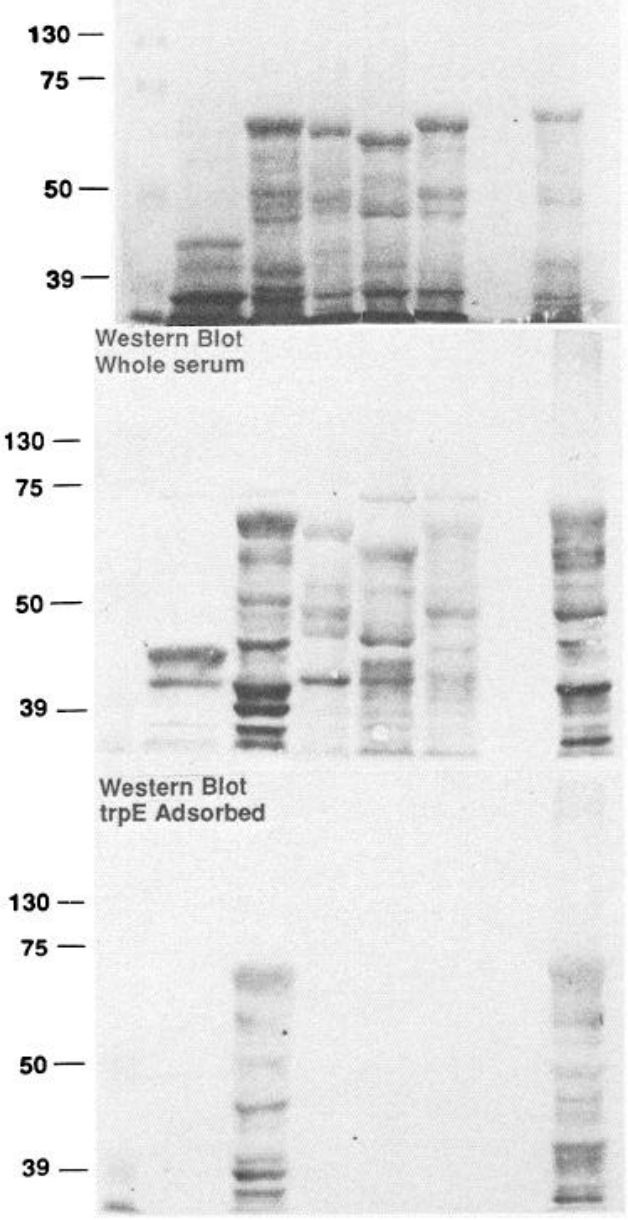

representation of the protein encoded by GluR1 (see Hollmann et al., 1989). A leader sequence and possible transmembrane domains (I-IV) are indicated by cross-hatching. Stippled portions were prepared as antigen using the trp $\mathrm{E}$ bacterial expression system as described in Materials and Methods. Two rabbits were injected with each antigen; rabbits E10 and E11 received protein prepared from the putative extracellular domain (residues 185-449), and rabbits $\mathrm{C} 72$ and $\mathrm{C} 73$ received antigen from the putative cytoplasmic domain through the carboxy terminus (residues 658-889). B, In the top gel, of Coomassie blue stained gel inclusion bodies from bacteria producing $\operatorname{tr} \mathrm{E}$ fusion proteins containing equivalent portions of the extracellular domain (see $A$ and Results) of GluR1 (R1), GluR2 (R2), GluR3 (R3), and GluR5 (R5). The trpE protein without a fusion extension is also shown $(\operatorname{trp} \mathrm{E})$, as is a $\operatorname{trp} \mathrm{E}$ fusion protein containing a longer portion of GluR1 $(R I L$; residues 185-521). In the center, a Western blot of proteins from an equivalent gel was produced, and immunoreactivity to whole serum E11 was visualized employing a goat anti-rabbit secondary antibody coupled to alkaline phosphatase. The bottom Western blot is equivalent to the center blot, except that E11 serum was incubated for $1 \mathrm{hr}$ at room temperature with the bacterial lysate used to produce the $\operatorname{trp} \mathrm{E}$ lane, cleared by centrifugation, and applied to the Western blot. E11 serum was used at 1:5000 dilution for both blots. Proteins of lower molecular weight than the fusion protein are degradation products generated during the preparation of inclusion bodies. 
Figure 2. Rabbit antisera to GluR1 and immunoreactivity toward crude membranes prepared from different regions of the rat brain. $A$, Immunostaining of antiserum $\mathrm{C} 73$ on a western blot of $500 \mu \mathrm{g}$ of crude membranes per lane prepared from the caudal brainstem (C. BRAIN STEM), cerebellum, rostral brainstem (R. BRAIN STEM), forebrain, and hippocampus as defined in Materials and Methods. A high concentration $(1: 250)$ of the immune serum was used to show the relative similarity in background among tissues. The 105-kDa protein seen on all blots developed with any of the antisera to GluR1 is indicated by an arrow. Additional proteins of $97 \mathrm{kDa}$ (asterisk) and $170 \mathrm{kDa}$ (arrowhead) are detected by some antisera to GluR1. The molecular-weight markers were myosin, $200,000 \mathrm{Da} ; E$. coli $\beta$-galactosidase, $116,250 \mathrm{Da}$; phosphorylase, $97,400 \mathrm{Da}$; BSA, 66,200 Da; and hen egg white ovalbumin, 42,699 Da (Bio-Rad, Richmond, CA). B, Western blots of $500 \mu \mathrm{g}$ of crude hippocampal membranes per lane showing immunoreactivity toward rabbit $\mathrm{C} 73$ preimmune serum or $\mathrm{C} 73$ antiserum (left) or E11 preimmune serum and E11 antiserum (right).

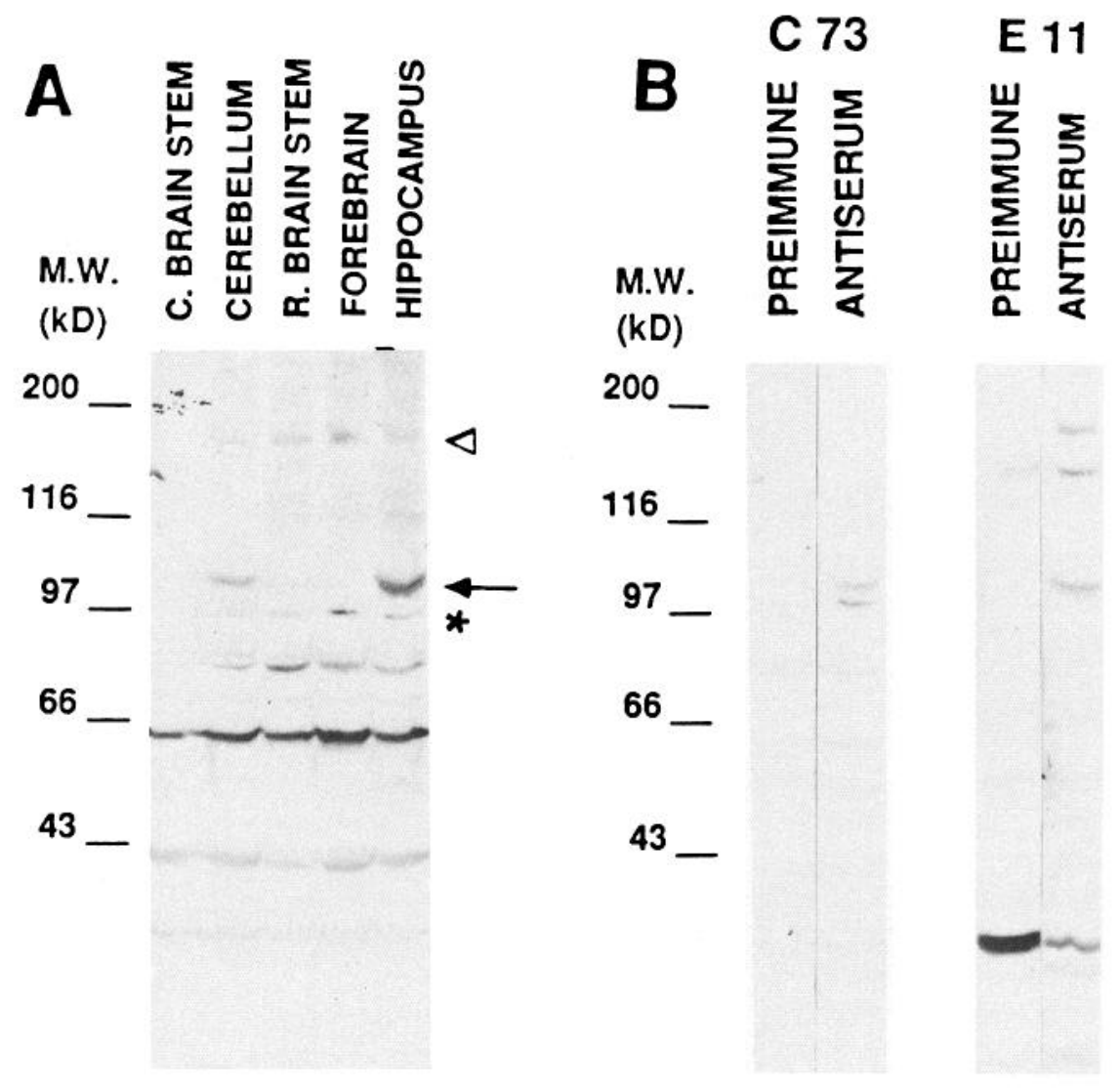

a similar tissue distribution as the $105-\mathrm{kDa}$ species, but they react differently to antisera $\mathrm{C} 73$ and E11 (Fig. $2 B$ ), and the intensity of labeling of these proteins varies between membrane preparations (cf. Fig. $2 A, B$ ). Antiserum C73 recognizes the 97 $\mathrm{kDa}$ protein, but the $170-\mathrm{kDa}$ protein is only weakly detected by this antiserum. The immunoreactivity of antiserum E11 toward the $97-\mathrm{kDa}$ protein is very weak, but it is stronger toward the $170-\mathrm{kDa}$ protein. Other low-molecular-weight bands $(<90$ $\mathrm{kDa}$ ) are observed in blots developed with $\mathrm{C} 73$ or E11, but they are also observed on blots exposed to preimmune serum (Fig. 2B).

\section{The 105-kDa and 170-kDa proteins are observed in cultured} cells transfected with GluR1

To test the hypothesis that the antisera react to the protein encoded by GluR 1, cultured cells were transfected with the cDNA encoding the GluR 1 receptor. The GluR 1 cDNA was subcloned into the SV40 expression vector pECE containing the HSVthymidine kinase gene (see Materials and Methods). This vector was transfected by the calcium phosphate method into cultured Rat $2\left(\mathrm{Tk}^{-}\right)$cells, and transfectants were selected for growth in HAT-containing medium. Cell lines were screened for the expression of GluR1 RNA using Northern analysis (Fig. 3A), positive cell lines were expanded, crude cell membranes were prepared, and Western blot analysis was performed. As shown in Figure $3 B$, antisera $C 73$ and E1 1 identified a protein of $105 \mathrm{kDa}$ in the cells expressing GluR1 RNA that is not present in membrane preparations from nontransfected Rat 2 cells. The $97-\mathrm{kDa}$ protein seen in rat CNS preparations is not observed in transfected cells. However, as shown in Figure $3 B$, the E11 antiserum detected the $170-\mathrm{kDa}$ protein. This result is consistent with the conclusion that the $105-\mathrm{kDa}$ protein is the product of GluR1 and suggests that the $170-\mathrm{kDa}$ band also arises from a translational product of the GluR1 cDNA (see Discussion).

\section{The protein detected by GluRI antisera is glycosylated}

Deglycosylation was used to explore the relationship between the $105-\mathrm{kDa}$ and $97-\mathrm{kDa}$ proteins. Hippocampal crude membranes were incubated with either endoglycosidase $\mathrm{H}$ or $\mathrm{N}$-glycosidase $\mathrm{F}$, in the presence and absence of protease inhibitors. As shown in Figure 3, the molecular weight of the 105$\mathrm{kDa}$ protein is reduced to $100-\mathrm{kDa}$ by digestion with endoglycosidase $\mathrm{H}$ and to $97-\mathrm{kDa}$ by digestion with $\mathrm{N}$-glycosidase $\mathrm{F}$. No change was observed in the molecular weight of the $97-\mathrm{kDa}$ protein. It is possible that the $97-\mathrm{kDa}$ protein is a nonglycosylated form of the $105-\mathrm{kDa}$ protein. However, the preservation of the $97-\mathrm{kDa}$ protein during deglycosylation was dependent upon the addition of a broad spectrum of protease inhibitors to the reaction mixture (Fig. 4), while deglycosylated 105-kDa protein was not degraded even in the absence of protease inhibitors (see the discussion of the $97-\mathrm{kDa}$ protein below). The $170-\mathrm{kDa}$ band was inconsistently observed on Western blots developed with antiserum C73 (as noted above; see also Fig. $2 A$ ), and though difficult to see in Figure 4, its presence is independent of the addition of protease inhibitors.

\section{Membrane fractionation studies reveal that GluR1-related immunoreactivity is enriched in postsynaptic densities}

Membrane fractionation was used to determine the subcellular distribution of the $105-\mathrm{kDa}$ protein band. Hippocampal crude 


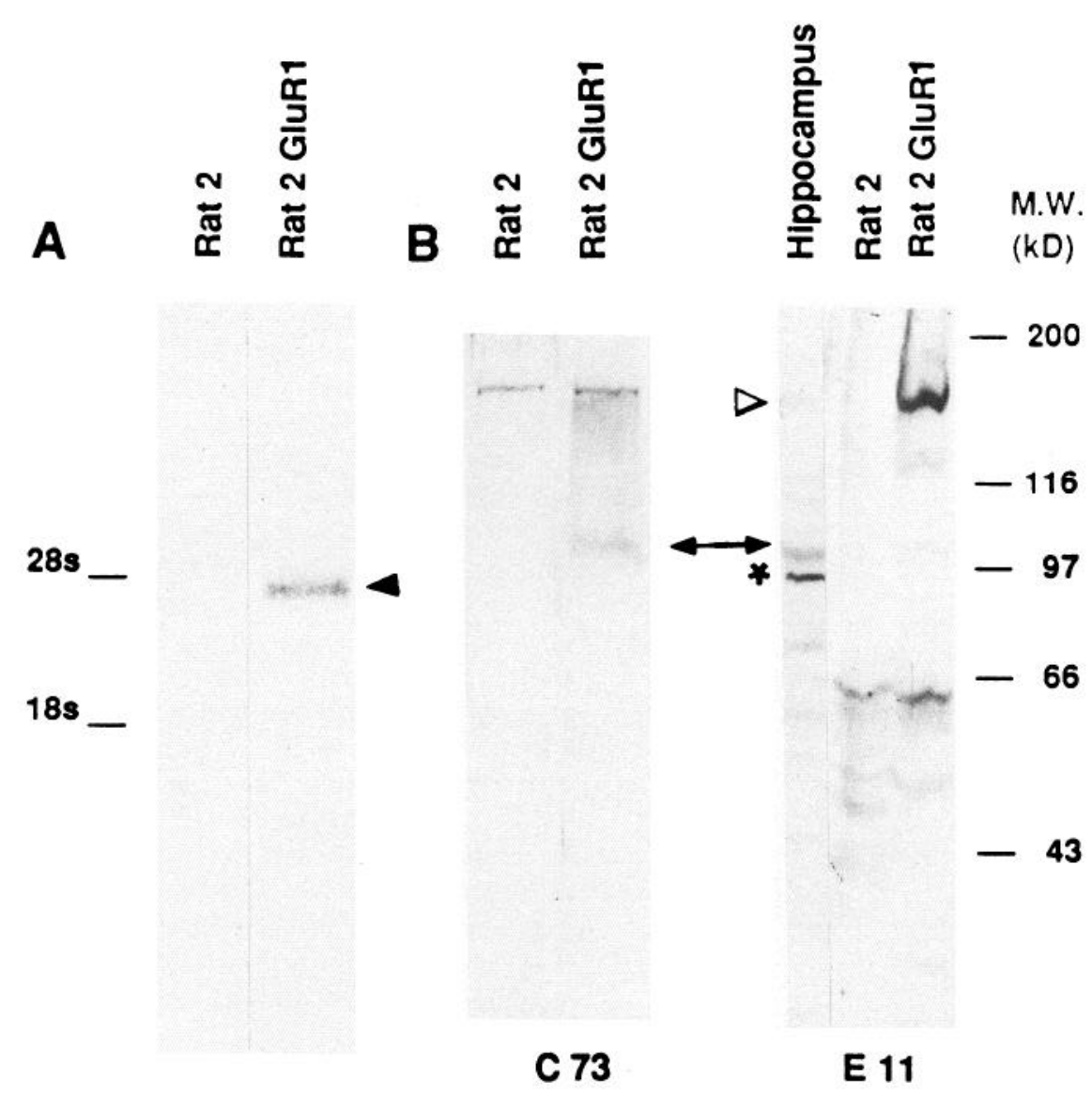

Figure 3. Analysis of cultured cells transfected with GluR1. $A$, Northern blot analysis of $20 \mu \mathrm{g}$ total RNA isolated from Rat 2 fibroblasts or Rat 2 fibroblasts transfected with the cDNA encoding GluR1 (see Materials and Methods). ${ }^{32} \mathrm{P}$-labeled probe was made from the full-length GluR $1 \mathrm{cDNA}$, and the blot was exposed to Kodak X-OMAT film for $24 \mathrm{hr}$ at $-70^{\circ} \mathrm{C}$ in the presence of a Lightning-Plus intensifier screen. The solid arrowhead points to a band seen only in transfected cells. $B$, Western blot analysis of $200 \mu \mathrm{g}$ of crude membranes per lane prepared from either Rat 2 or Rat 2 cells transfected with the GluR1 cDNA (see Materials and Methods). The blot on the left $(10 \%$ SDS-polyacrylamide gel) was developed with the rabbit antiserum C73 (1: 400 dilution). The blot on the right $(7.5 \%$ SDS-polyacrylamide gel) shows immunoreactivity of the antiserum E11 (1:400 dilution). For comparison, one lane (Hippocampus) shows immunoreactivity of antiserum $\mathrm{C} 73$ to $500 \mu \mathrm{g}$ of rat hippocampal crude membranes as in Figure 2. Molecular-weight markers are shown for the Western blot on the right, and both gels were aligned at the 105-kDa band (arrow). Proteins of $97 \mathrm{kDa}$ (asterisk) and $170 \mathrm{kDa}$ (open arrowhead) are also indicated. membranes were fractionated by lysis and centrifugation through a three-step sucrose gradient to isolate SPMs, a particulate fraction that contains mitochondria, and myelin. SPMs were solubilized in Triton X-100 and centrifuged at 105,000 $\times g$ through a 1-M sucrose cushion to pellet PSDs. The supernatant of this fraction was also saved for analysis. Protein from each preparation was fractionated on SDS-polyacrylamide gels and then transferred to nitrocellulose. The blot was photographed and then scanned with a Hoefer GS300 Scanning Densitometer, and the relative intensity of each band was calculated (not shown). Both antisera C73 and E11 revealed that the $105-\mathrm{kDa}$ species copurifies with the SPM fraction and that it is enriched in PSDs (Fig. 5) by more than 140-fold over crude hippocampal membranes. In comparison, the PSD fraction was enriched only fivefold over hippocampal crude membranes. In addition, most proteins detected nonspecifically by the preimmune sera (Fig. $2 B$ ) were found in the particulate fraction (Fig. 5).

These fractionation studies reveal that the $97-\mathrm{kDa}$ protein has properties different from those of the $105-\mathrm{kDa}$ protein. Hippocampal tissue homogenate was separated into soluble and insoluble fractions by centrifugation at $300,000 \times g$ for $90 \mathrm{~min}$. Western blot analysis shows that the $105-\mathrm{kDa}$ and $170-\mathrm{kDa}$ proteins are exclusively in the sedimented fraction, but essentially all of the $97-\mathrm{kDa}$ protein is in the $300,000 \times g$ supernatant (Fig. 5). This result, taken together with the absence of detectable glycosylation of the $97-\mathrm{kDa}$ protein, indicates that this protein is not an integral membrane protein.

\section{The localization of GluR1-related immunoreactivity within neurons of the cerebellum and limbic system}

Immunohistochemistry with antisera C73, E10, and E11 was used to determine the distribution of the GluR1 protein in the rat brain. Antiserum E11 produces staining that is particularly robust, but qualitatively similar to antiserum E10. Although antiserum $\mathrm{C} 73$ produced immunostaining patterns similar to E10 and E11, these results are not included in this part of the article because of the additional reactivity of this antiserum toward the $97-\mathrm{kDa}$ protein.

The E11 immunoreactivity is found exclusively in neurons (Fig. 6A), where it labels throughout their somata, dendrites, and frequently the initial segments of their axons. This pattern of expression is particularly apparent in the cerebellum, where the somata and dendritic arbors of the Purkinje cells are prominently labeled (Fig. 6B). The strong intracellular labeling is of interest because similar staining for other members of the ligand-gated ion channel family such as the neuronal nicotinic ACh receptors (Jacob et al., 1983; Swanson et al., 1987; Keyser et al., 1988) has also been observed. The significance of this intense "cytoplasmic" staining is not known, but others have suggested that this may represent an intracellular pool of receptor precursors or subunits being assembled (Stollberg and Berg, 1987).

A comparison of the GluR1 RNA as localized by in situ hybridization histochemistry and the results of immunohisto- 


\section{NO TREATMENT \\ $37^{\circ} \mathrm{C} 4$ HOURS}

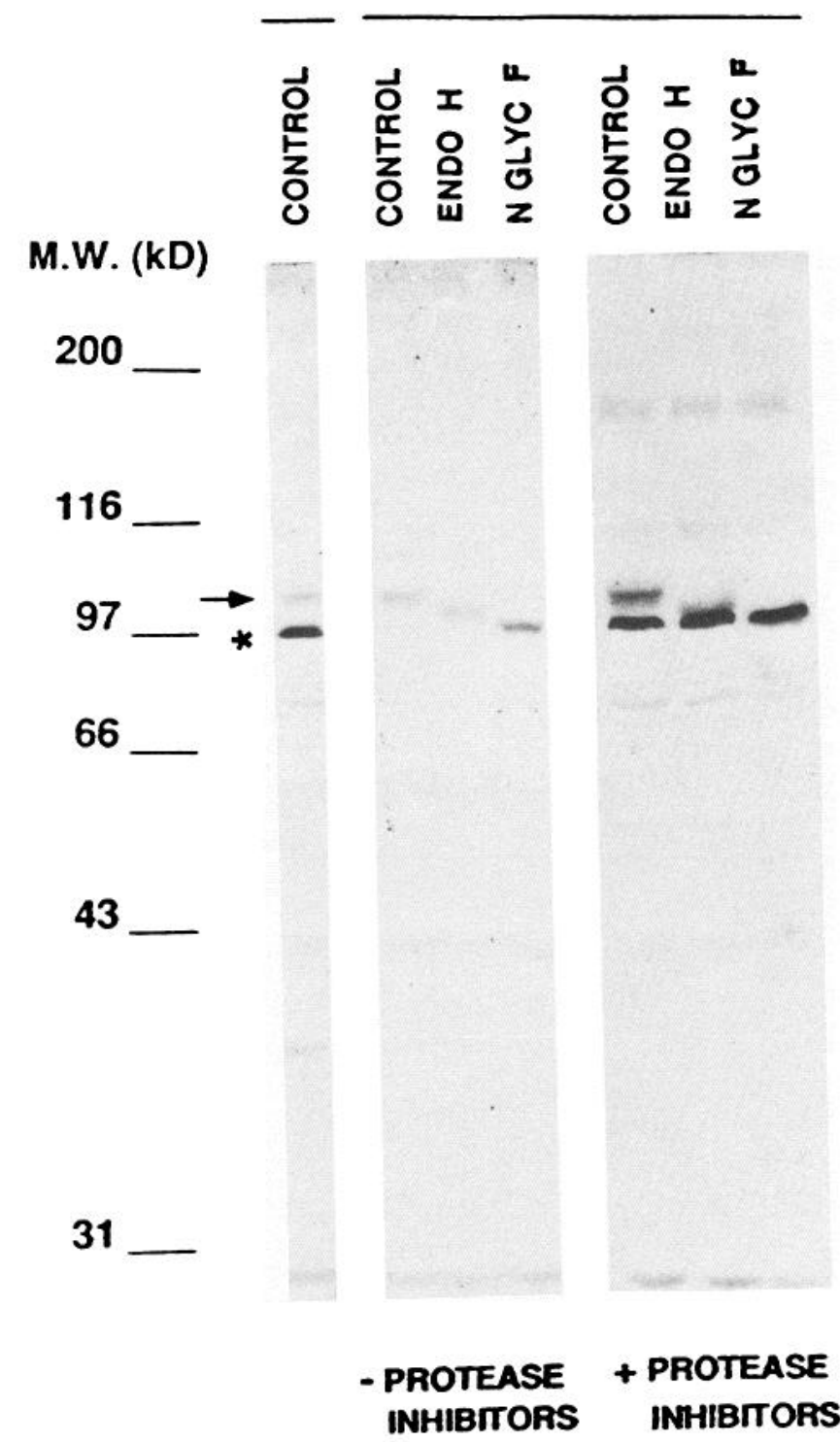

Figure 4. Glycosidase treatment of rat hippocampal crude membranes. Rat hippocampal crude membranes $(700 \mu \mathrm{g} /$ lane) were deglycosylated with either endoglycosidase $\mathrm{H}$ or $\mathrm{N}$-glycosidase $\mathrm{F}$, separated by gel electrophoresis, and transferred to nitrocellulose, and immunoreactivity toward antiserum $\mathrm{C} 73$ was determined. The first lane labeled Control shows immunoreactivity toward hippocampal crude membranes prepared as in Figure 2. The other six lanes show the results for hippocampal crude membranes that were incubated for $4 \mathrm{hr}$ at $37^{\circ} \mathrm{C}$ in buffers containing either no endoglycosidase (Control), endoglycosidase $\mathrm{H}$ (ENDO $H$ ), or N-glycosidase $\mathrm{F}(N G L Y C F)$. Reaction mixtures for the samples in the first three lanes contained no protease inhibitors, whereas those in the next three lanes contained a protease inhibitor cocktail (see Materials and Methods). Proteins of $105 \mathrm{kDa}$ (arrow) and $97 \mathrm{kDa}$ (asterisk) are indicated. The molecular-weight markers are as in Figure 2 with the addition of bovine carbonic anhydrase, 31,000 Da.

chemistry reveal an overlapping pattern of expression. For example, in the hippocampus, both message (Fig. $6 \mathrm{C}$ ) and immunoreactivity (Fig. $6 D$ ) are distributed throughout Ammon's horn and the dentate gyrus. However, while the RNA is confined to the somata of the neurons, the protein product is also distributed throughout the neuropil. This is best seen in $\mathrm{CA}_{1}$, where the labeled pyramidal cell somata give rise to densely labeled primary dendrites that extend into the stratum radiatum. There is also a fine punctate labeling of the neuropil that extends throughout the stratum oriens, stratum radiatum, and stratum lacunosum-moleculare. Although in situ hybridization has always detected message in the regions of the brain that are intensely immunoreactive, there are also regions where message is seen but detectable immunoreactivity is absent. For example, in the medial portion of the habenula, a strong message signal is observed, but no immunoreactivity has been detected (not shown; see Hollmann et al., 1991). Also, in situ hybridization reveals that the message is distributed evenly in the $\mathrm{CA}_{1}$ and $\mathrm{CA}_{3}$ regions, but immunohistochemistry demonstrates some differences in the protein labeling between these regions. A notable difference is seen in the stratum lucidum of $\mathrm{CA}_{3}$, which often lacks the fine punctate labeling pattern seen in the other layers and contains only labeling of the thick processes of adjacent pyramidal cells. In the dentate gyrus, immunoreactivity is observed throughout the molecular layer, and it is concentrated within the somata of the granule cell and polymorph layers, consistent with the distribution of GluR1 message.

In addition to the hippocampus, there are intensely immunoreactive neurons in several other regions of the limbic system. These include the amygdala, the bed nuclei of the stria terminalis, and parts of the septum. The strongest labeling of the entire forebrain is concentrated within the somata and processes of densely packed oval neurons of the central nucleus of the amygdala (Fig. 6E) as defined by Brodal (1947) and Krettek and Price $(1978 \mathrm{a}, \mathrm{b})$. The dendrites of these cells are strongly labeled and form such a dense plexus that the entire neuropil appears labeled in $30-\mu$ m-thick sections. Brodal (1947) noted that the rostral portions of the central nucleus are difficult to define and that it gradually appears to merge with the most ventral border of the putamen. Indeed, at the rostral end of the well-defined central nucleus, there is a continuation of a few labeled cells in the sublenticular substantia innominata that extends rostrally to the level of the anterior commissure and bed nuclei of the stria terminalis (a part of the "extended amygdala"; Alheid and Heimer, 1988). Caudally, the nucleus diminishes rapidly. Labeled axons can be followed from the cells within the central nucleus into the stria terminalis, which itself contains a few labeled cells and fibers throughout its course along the lateral ventricle to the bed nuclei of the stria terminalis.

The labeled fibers of the stria end in several subdivisions of the bed nuclei, each of which also contains many labeled somata (Fig. $6 F$ ). Principle among these are the oval and juxtacapsular nuclei (Ju and Swanson, 1989; Ju et al., 1989), which are packed with densely labeled, medium-sized, oval cells. There are also labeled fusiform cells scattered along the margins of the anterior commissure in the subcommissural zone, fusiform nucleus, and anterolateral area of Ju and Swanson (1989).

In the septum, there is an extensive labeling of the lateral division (Fig. 6F). Unlike the hippocampus, this label is concentrated largely within the somata and initial dendrites of large cells, and there is little of the punctate labeling seen in the hippocampal neuropil. The labeled neurons are spread throughout the dorsal, intermediate, and ventral subdivisions of the lateral septum (as described by Swanson and Cowan, 1979). The labeling in the dorsal and intermediate divisions of the septum is within large multipolar neurons and extends down their large, often spiny, dendrites. In the ventral division, the labeling is in somewhat smaller, oval cells. 


\section{Fractions}

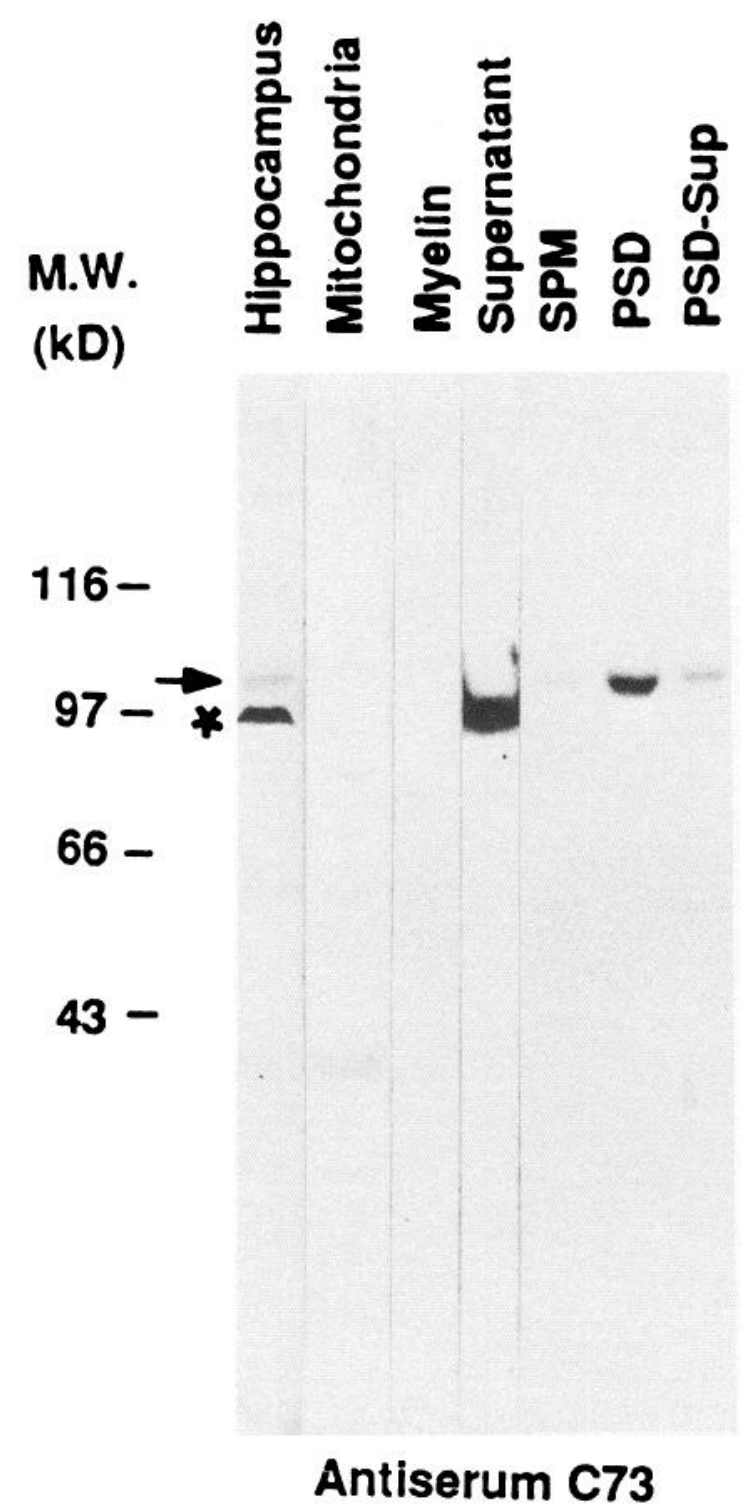

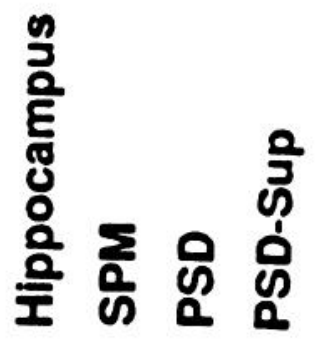

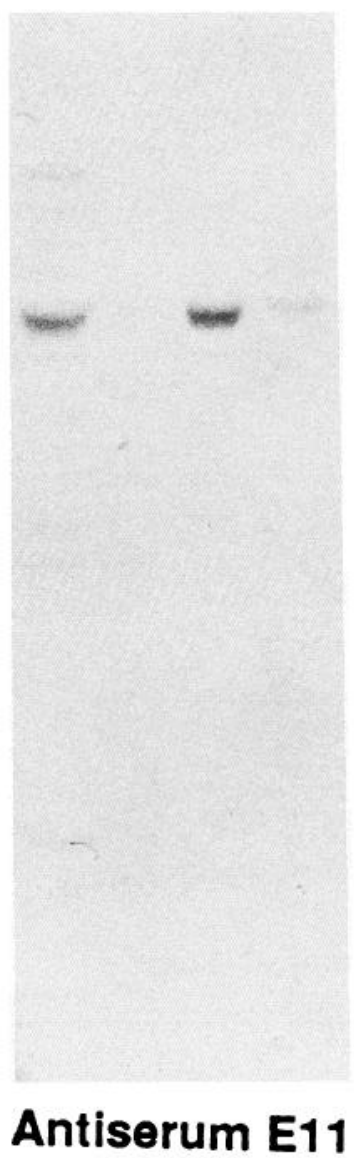

Figure 5. Subcellular fractionation of the rat hippocampus. Freshly obtained rat hippocampal tissue was homogenized and fractionated as described in Materials and Methods. The proteins from each fraction were separated by gel electrophoresis, and Western blots were prepared. The amount of total protein added to each gel lane was as follows: crude membranes (Hippocampus), $500 \mu \mathrm{g}$; particulate fraction (Mitochondria), $100 \mu \mathrm{g}$; Myelin, $100 \mu \mathrm{g}$; $300,000 \times g$ supernatant of the homogenate (Supernatant), $100 \mu \mathrm{g}$; SPM, $50 \mu \mathrm{g} ; P S D, 50 \mu \mathrm{g}$; PSD supernatant (PSD-Sup), $50 \mu \mathrm{g}$. The blot on the left shows the immunoreactivity of rabbit antiserum $\mathrm{C} 73$ toward proteins from all fractions. The blot on the right shows the immunoreactivity of rabbit antiserum E11 toward selected hippocampal fractions. Proteins of $105 \mathrm{kDa}$ (arrow) and $97 \mathrm{kDa}$ (asterisk) are indicated.

\section{Discussion}

The following evidence supports the conclusion that the protein product of GluR1 and possibly closely related members of this gene family are glycoproteins of approximately $105 \mathrm{kDa}$ that are enriched in the PSDs of neurons: First, antisera raised to bacterial fusion proteins made to two nonoverlapping portions of GluR 1 are immunoreactive to a $105-\mathrm{kDa}$ band present in rat brain as seen by Western analysis, and the antisera E10 and E11 do not react on Western blots with the equivalent protein region of GluR2, GluR3, and GluR5. Second, a 105-kDa protein is expressed in cultured Rat 2 fibroblasts when they are transfected with the GluR1 cDNA. Third, upon deglycosylation, the apparent molecular weight of the $105-\mathrm{kDa}$ band is reduced to 97 $\mathrm{kDa}$, which is compatible with the molecular weight of about $100 \mathrm{kDa}$ predicted from the GluR1 cDNA. Fourth, subcellular fractionation reveals that the $105-\mathrm{kDa}$ protein is associated with membrane fractions and that it is enriched in PSDs. This is consistent with immunohistochemical results that show the distribution of antigen to be in the somata and dendrites of neurons. Finally, the distribution of GluR1 gene expression, as determined by in situ hybridization histochemistry, is neuronal, and it is consistent with the results of the immunohistochemical analysis.

In addition to the $105-\mathrm{kDa}$ species, antisera raised against GluR1 detect 97-kDa and 170-kDa proteins. Because 105-kDa and $170-\mathrm{kDa}$ proteins are observed in cultured cells subsequent to transfection with the cDNA encoding GluR1, the $170-\mathrm{kDa}$ protein may be related to the $105-\mathrm{kDa}$ protein, possibly through posttranslational modifications or aggregation. The $97-\mathrm{kDa}$ protein appears to be different from the $105-\mathrm{kDa}$ protein. This conclusion is supported by three lines of evidence. First, the 97$\mathrm{kDa}$ band is not found in cell lines transfected with GluR1. Second, the $97-\mathrm{kDa}$ protein is probably a soluble cytoplasmic 

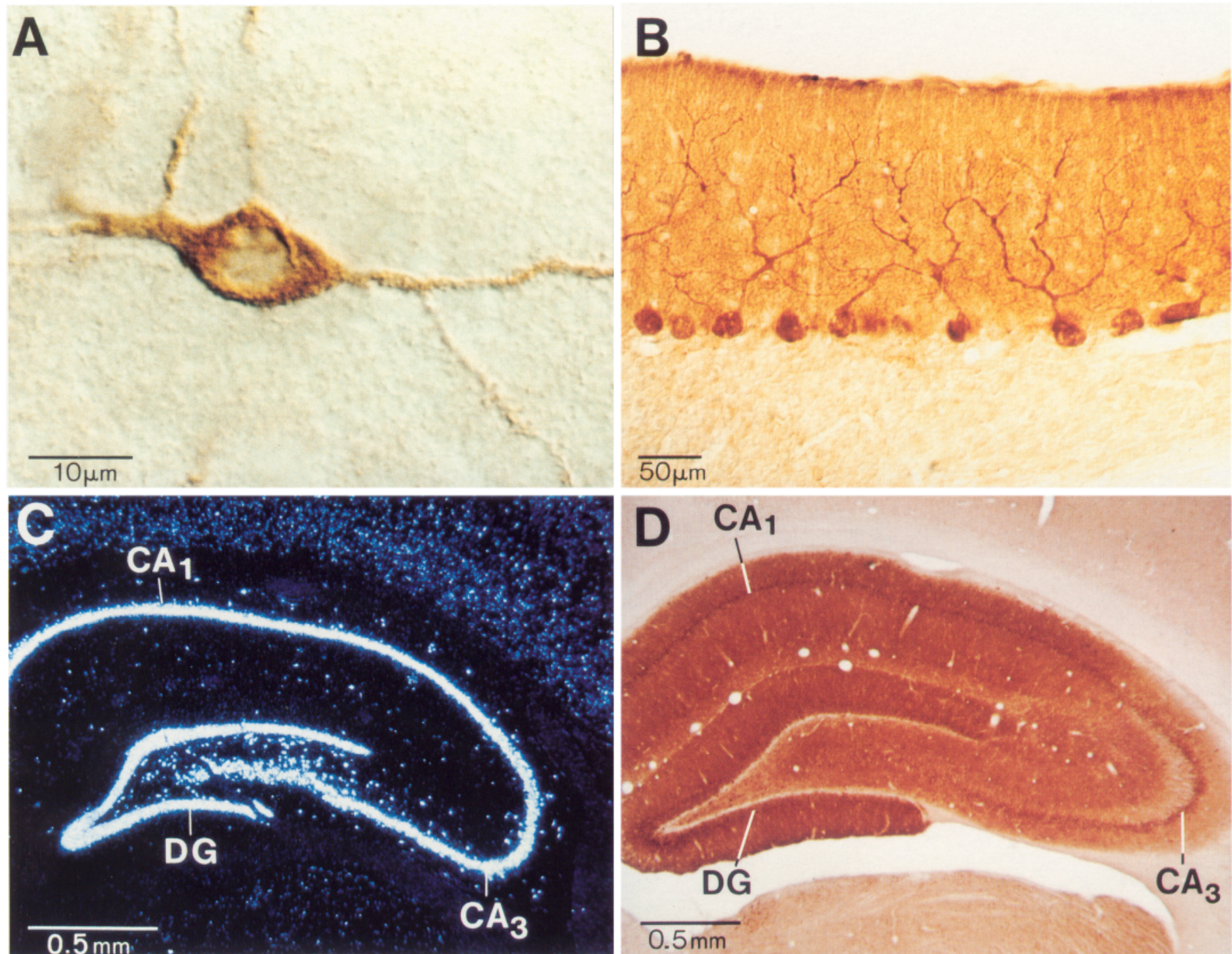

\section{$\overline{50 \mu \mathrm{m}}$}
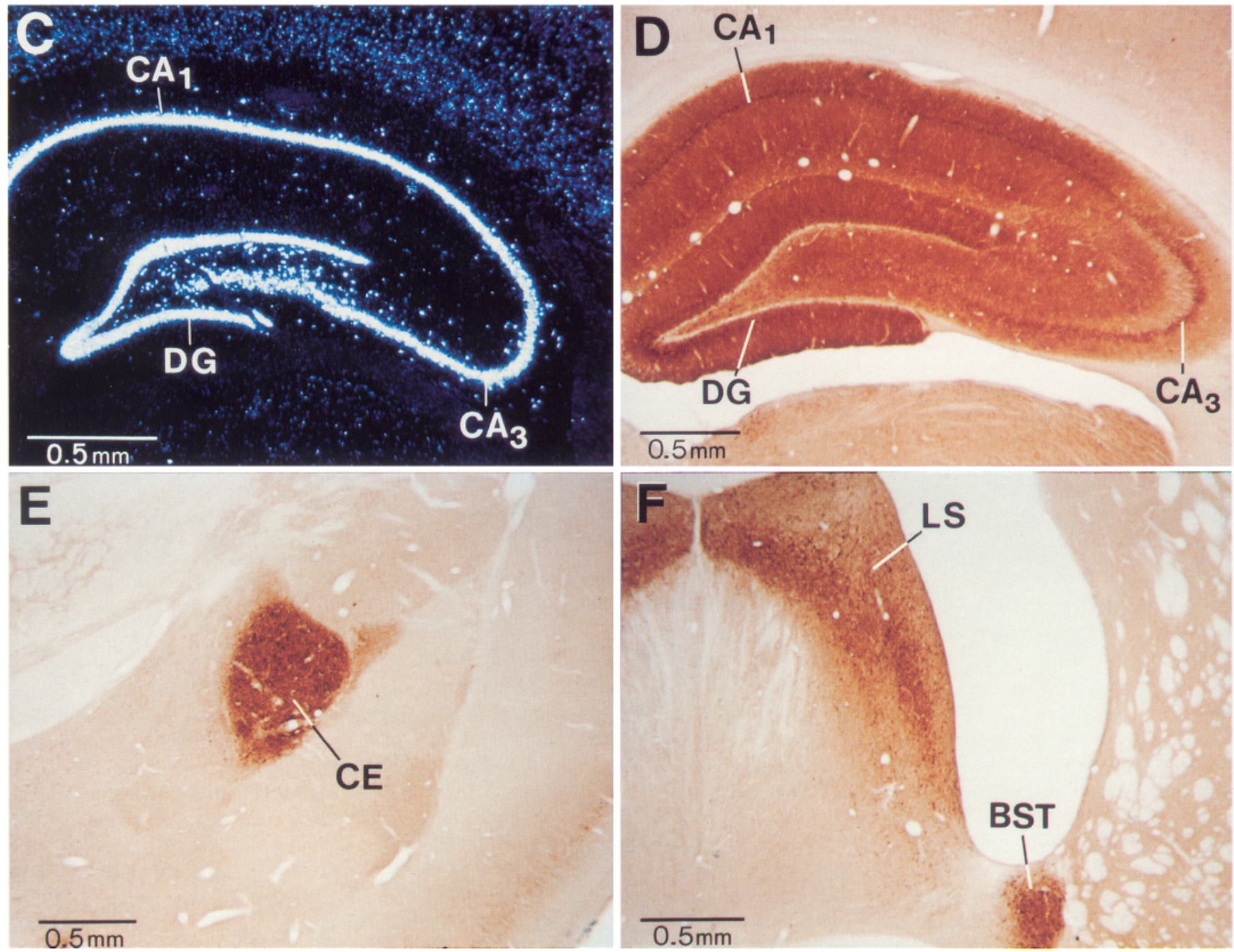

Figure 6. Histochemical localization of GluR1 message and related immunoreactivity. $A$, The antiserum E11 labels the somata and dendrites of some neurons in the rat brain. $B$, Labeling of Purkinje cells in the cerebellum by antiserum E11 reveals both their somata and thick dendritic arbors. As shown for the hippocampus $(C, D)$, there is a good correspondence between the distribution of message for GluR1 $(C)$ and the protein product $(D)$. Both message and protein immunoreactivity are present in the somata of Ammon's horn $\left(C A_{l}\right.$ and $C A_{3}$ are indicated) and the dentate gyrus $(D G)$. The immunoreactivity also extends into the processes that extend throughout the adjacent neuropil. Antiserum E11 strongly labels several other regions of the limbic system, including the central nucleus of the amygdala, $(E, C E)$, and, as shown in $F$, the lateral septum $(L S)$ and the lateral group of the bed nuclei of the stria terminalis $(B S T)$. Sections developed with E11 preimmune serum at the same dilution as immune serum (1:3000) showed no detectable staining (data not shown). 


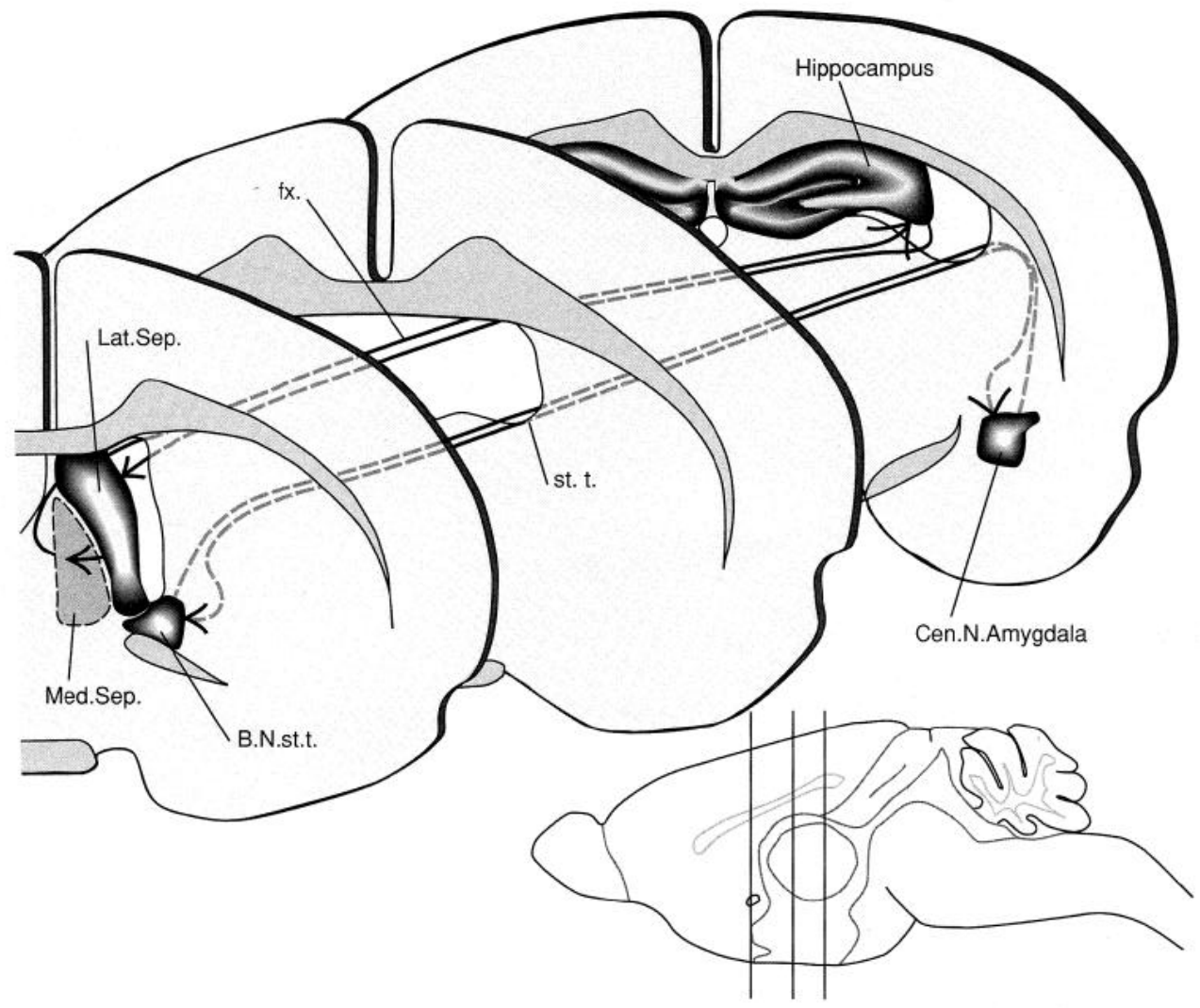

Figure 7. Schematic illustration of the heavily receptor-positive structures (dark shading), and their interconnections (relative rostrocaudal positions of the sections illustrated on the parasaggital section, bottom right). The hippocampus projects via the fornix $(f x$.) to the lateral septum (Lat.Sep.), which in turn sends axons to the medial septum (Med.Sep.). The medial septum projects heavily back upon the hippocampus. In another, similar, pathway, the central nucleus of the amygdala (Cen.N.Amygdala) is reciprocally interconnected, via the stria terminalis (st.t.), with the lateral division of the bed nuclei of the stria terminalis (B.N.st.t.). protein because it is present in the $300,000 \times g$ supernatant of hippocampal tissue homogenates and it is not glycosylated. Third, protease inhibitors are required to preserve the immunoreactivity of the $97-\mathrm{kDa}$ protein, whereas the $105-\mathrm{kDa}$ protein is stable in the absence of protease inhibitors. Several possibilities exist for the reactivity of the GluR1-directed antisera to the 97$\mathrm{kDa}$ protein. For example, the $97-\mathrm{kDa}$ protein may share a common immunological epitope with the GluR1 protein, but they are otherwise unrelated. Alternatively, the $97-\mathrm{kDa}$ protein might arise from the GluR1 gene through alternative splicing of the message or from the message of a gene closely related to GluR1. In this context, in addition to the recently reported cDNAs that encode proteins homologous to GluR1 (Bettler et al., 1990; Boulter et al., 1990b; Keinanen et al., 1990; Hollmann et al., 1991), it has recently been shown (Sommer et al., 1990) that splice variants of these clones are present in the CNS and that they confer slightly different pharmacological properties and localization (as determined by in situ hybridization) to the receptors encoded by them. Because it is likely that additional subunits will be identified, we cannot exclude the possibility that our antisera will react with other members of the glutamate receptor family. The degree of immunoreactivity among various closely related members of this family awaits further study. Nevertheless, despite the widespread distribution of the message for the receptor subunits of this family as reported in the above studies, and despite the indication that essentially all neurons contain glutamate receptors as determined by electrophysiology (Stevens, 1989), the antisera produced in this study reveal the strong expression of GluR1 in only a relatively small subset of interconnected nuclei.

Other proteins related to the GluR 1 family that bind ${ }^{3} \mathrm{H}$ - kainate have been found in the frog (Hampson and Wenthold, 1988; Hampson et al., 1989), chicken (Gregor et al., 1988), and pigeon (Klein et al., 1988), but these proteins are in the molecular-weight range of $48-50 \mathrm{kDa}$. DNAs encoding proteins that are similar to these have been isolated from frog $(\mathrm{K}$. Wada et al., 1989) and chicken (Gregor et al., 1989). Although the frog cDNA encodes a protein with high sequence identity to the second half of GluR 1 and that binds ${ }^{3} \mathrm{H}$-kainate with high affinity upon transfection into cultured cells (K. Wada et al., 1989), the function of these kainate-binding proteins is not yet established. Using antibodies directed toward these kainate-binding proteins, Eshhar et al. (1989) and Somogyi et al. (1990) found immunoreactivity on Bergmann glial cells, whereas Dechesne et al. (1990) reported the staining of neurons and their axons in the frog brain. In either case, the pattern of localization is quite different from the one reported here. However, Hampson et al. (1989) found that an antibody made to the frog kainate-binding protein reacted with both $48-\mathrm{kDa}$ and $99-\mathrm{kDa}$ proteins on Western blots of rat brain proteins. Although we observed no immunoreactivity toward proteins in the molecular-weight range of $48-50 \mathrm{kDa}$, the $99-\mathrm{kDa}$ protein reported by Hampson et al. (1989) is similar to the molecular weights of the 105-kDa or the $97-\mathrm{kDa}$ proteins observed in this study.

How well does the distribution in the brain of the GluR1 subunit coincide with that of the glutamate receptors as determined by the binding of ligands such as ${ }^{3} \mathrm{H}$-kainate, ${ }^{3} \mathrm{H}-(R, S)$ $\alpha$-amino-3-hydroxy-5-methyl-isoxazole-4-propionate (AMPA), or ${ }^{3} \mathrm{H}-\mathrm{NMDA}$ ? Although there is generally good agreement between the results of these studies (e.g., Monaghan and Cotman, 1982; Monaghan et al., 1983; Unnerstall and Wamsley, 1983; Cotman et al., 1987; Insel et al., 1990; Miller et al., 1990) and 
the labeling for GluR1, there are notable differences. For example, in the hippocampus, GluR1-related immunoreactivity is seen throughout Ammon's horn and the dentate gyrus, yet binding of ${ }^{3} \mathrm{H}$-kainate is predominantly localized to the $\mathrm{CA}_{3}$ region, and ${ }^{3} \mathrm{H}$-AMPA binding is most intense in the $\mathrm{CA}_{1}$ region and the dentate gyrus (Monaghan and Cotman, 1982; Monaghan et al., 1983; Unnerstall and Wamsley, 1983; Cotman et al., 1987; Miller et al., 1990). These discrepancies suggest that the general correspondence between ligand binding and GluR 1-related immunoreactivity could be fortuitous, especially bccausc glutamate receptors are enriched in the limbic system, where our most intense immunoreactivity is observed. Further, comparisons are complicated by additional factors such as an uncertainty as to which ligands are bound by GluR 1 and homologous receptors in ligand-binding studies. This problem is particularly evident when the results of electrophysiology and radioligand binding to GluR I expressed in Xenopus oocytes or cultured cells are compared. Although GluRl is activated by kainate and to a lesser extent by AMPA (Boulter et al., 1990b; Keinanen et al., 1990; Hollmann et al., 1991), the expression of GluR1 in cultured cells results in the appearance of high-affinity ${ }^{3} \mathrm{H}$-AMPA but not ${ }^{3} \mathrm{H}$-kainate binding sites (Keinanen et al, 1990). In addition, it is likely that the binding or specificity of any ligand toward GluRl-related proteins will vary if it is part of a glutamate receptor complex formed by heterologous subunits. Finally, the distribution of kainate-binding proteins further complicates, and could obscure, meaningful comparisons between radioligand binding and the distribution of GluR 1 -related immunoreactivity. Clearly, the distribution of glutamate receptor subtypes as determined from radioligand binding studies will require further evaluation as the proteins that bind these compounds are identified and functionally characterized.

Although the correspondence between radioligand binding and GluR1 distribution is unclear, there is electrophysiology and excitotoxicity evidence that non-NMDA receptors exist in the cell groups labeled in this study. For example, non-NMDA glutamate receptors are found in Purkinje cells (Cull-Candy and Usowicz, 1987). In the hippocampus, many of the fiber systems, including the perforant path, mossy fiber, and Schaffer collaterals, act in part through non-NMDA receptors (reviewed by Collingridge and Lester, 1989). In the lateral septum, a region rich with reccptor-positive large spiney cells, it has been shown that the hippocampal input acts via both the NMDA (Gallagher and Hasuo, 1989a,b) and the non-NMDA receptors (Joels and Urban, 1984a,b; Stevens and Cotman, 1986). Finally, when lesions in the brain are induced by high doses of kainic acid, neuronal death occurs in all fields of the hippocampus, the lateral septum, the amygdala, and nearly all of the neurons in the lateral division of the bed nuclei of the stria terminalis (Nadler et al., 1978; Nitecka et al., 1984; Ben-Ari, 1985).

The excitatory amino acid receptors are thought to be on neurons throughout the CNS (Stevens, 1989); however, the immunoreactivity toward protein prepared from GluR 1 is largely restricted to portions of the limbic system. There is a particularly strong correspondence between the hippocampal projection to the lateral septum (Swanson and Cowan, 1979) and the receptor labeling seen there. Because this projection is thought to use glutamate as its neurotransmitter (revicwed by Cotman ct al., 1987; Swanson et al., 1987b), it seems likely that GluR1 and closely related proteins are part of the postsynaptic receptor system that is involved in this input. Because the lateral septum projects to the medial septum, and because the medial septum has a cholinergic projection to the hippocampus (see Fig. 7), it is possible that GluR1-related labeling reflects an extra-hippocampal excitatory feedback loop. The receptor labeling in the amygdala and bed nuclei of the stria terminalis parallel this arrangement (Fig. 7), because the bed nuclei of the stria terminalis can be thought of as the septal target of the amygdala (reviewed by Swanson et al., 1987b). This circuit, however, may be especially noteworthy because the central nucleus and the bed nucleus are reciprocally interconnected (Krettek and Price, 1978a; Swanson and Cowan, 1979). If the neurons in cach nucleus make direct synaptic contact with the efferent neurons of the other nucleus, this suggests that the two groups of cells are interconnected in a "glutamate loop." Such a glutamate circuit could conceivably give rise to the focal seizure activity caused by intra-amygdaloid stimulation (Mori and Wada, 1987; Croucher and Bradford, 1990). This is particularly important because there is evidence that focal seizures in humans start in the temporal lobe and because injections of kainic acid into the amygdala of the rat are used as a model for temporal lobe epilepsy (reviewed by Ben-Ari, 1985).

\section{References}

Albin RL, Young AB, Penny JB, Handelin B, Balfour R, Anderson KD, Markel DS, Tourtellotte WW, Reiner A (1989) Abnormalities of strial projection neurons and $N$-methyl-D-aspartate receptors in presymptomatic Hunington's disease. N Engl J Med 322:1293-1298.

Alheid GF, Heimer L (1988) New perspectives in basal forebrain organization of special relevance for neuropsychiatric disorders: the striatopallidal, amygdaloid, and corticopetal components of substantia innominata. Neuroscience 27:1-39.

Barnard EA, Darlison MG, Seeburg P (1987) Molecular biology of the $\mathrm{GABA}_{\mathrm{A}}$ receptor: the receptor/channel superfamily. Trends Neurosci 10:502-509.

Ben-Ari Y (1985) Limbic seizure and brain damage produced by kainic acid: mechanisms and relevance to human temporal lobe epilepsy. Neuroscience 14:375-403.

Bettler B, Boulter B, Hermans-Borgmeyer I, O'Shea-Greenfield A, Deneris E, Moll C, Borgmeyer U, Hollmann M, Heinemann S (1990) Cloning of a novel glutamate receptor subunit, GluR5: expression in the nervous system during development. Neuron 5:583-595.

Boulter J, O'Shea-Greenfield A, Duvoisin RM, Connolly JG, Wada E, Jensen A, Gardner PD, Ballivet M, Deneris ES, McKinnon D, Heinemann S, Patrick J (1990a) $\alpha_{3}, \alpha_{5}$, and $\beta_{4}$ : three members of the rat neuronal nicotinic acetylcholine receptor-related gene family form a gene cluster. J Biol Chem 265:4472-4482.

Boulter J, Hollmann M, O'Shea-Greenfield A, Hartley M, Deneris E, Maron C, Heinemann S $(1990 \mathrm{~h})$ Molecular cloning and functional expression of glutamate receptor subunit genes. Science 249:10331037.

Brodal A (1947) The amygdaloid nucleus in the rat. J Comp Neurol 87:257-284.

Choi DW (1988) Glutamate neurotoxicity and diseases of the nervous system. Neuron 1:623-634.

Claudio T, Ballivet M, Patrick J, Heinemann S (1983) Nucleotide and deduced amino acid sequences of Torpedo californica acetylcholine receptor $\gamma$ subunit. Proc Natl Acad Sci USA 80:1111-1115.

Collingridge GL, Bliss TVP (1987) NMDA receptors-their role in long-term potentiation. Trends Neurosci 10:288-293.

Collingridge GL, Lester RAS (1989) Excitatory amino acid receptors in the vertebrate central nervous system. Pharmacol Rev 40:145-195.

Cotman CW, Monaghan DT, Ottersen OP, Storm-Mathisen J (1987) Anatomical organization of excitatory amino acid receptors and their pathways. Trends Neurosci 10:273-280.

Croucher MJ, Bradford HF (1990) NMDA receptor blockade inhibits glutamate-induced kindling of the rat amygdala. Brain Res 506:349352.

Cull-Candy SG, Usowicz MM (1987) Multiple-conductance channels activated by excitatory amino acids in cerebellar neurons. Nature 325 : $525-528$. 
Dechesne CJ, Oberdorfer MD, Hampson DR, Wheaton KD, Nazarali AJ, Goping G, Wenthold RJ (1990) Distribution of a putative kainic acid receptor in the frog central nervous system determined with monoclonal and polyclonal antibodies: evidence for synaptic and extrasynaptic localization. J Neurosci 10:479-490.

Deneris E, Boulter J, Connolly J, Wada E, Wada K, Goldman D, Swanson L, Patrick J, Heinemann S (1988a) Genes encoding neuronal nicotinic acetylcholine receptors. Clin Chem 35:731-737.

Deneris ES, Connolly J, Boulter J, Wada E, Wada K, Swanson LW, Patrick J, Heinemann S (1988b) Primary structure and expression of beta 2: a novel subunit of neuronal nicotinic acetylcholine receptors. Neuron 1:45-54.

Dieckmann CL, Tzagoloff A (1985) Assembly of the mitochondrial membrane system. J Biol Chem 260:1513-1520.

Ellis L, Clauser E, Morgan DO, Edery M, Roth RA, Rutter WJ (1986) Replacement of insulin receptor tyrosine residues 1162 and 1163 compromises insulin-stimulated kinase activity and uptake of 2-deoxyglucose. Cell 45:721-732.

Eshhar N, Roberts JDB, Teichberg BI, Somogyi P (1989) Localization of the cerebellar kainate receptors on Bergmann glial cells. Soc Neurosci Abstr 15:1162.

Gallagher JP, Hasuo H (1989a) Excitatory amino acid-receptor-mediated EPSPs in rat dorsolateral septal nucleus neurones in vitro. J Physiol (Lond) 418:353-365.

Gallagher JP, Hasuo H (1989b) Bicuculline- and phaclofen-sensitive components of $N$-Inethyl-D-aspartate-induced hyperpolarizations in rat dorsolateral septal nucleus neurones. J Physiol (Lond) 418:367377.

Greenamyre JT, Young AB (1989) Excitatory amino acids and Alzheimer's disease. Neurobiol Aging 10:593-602.

Gregor P, Eshhar N, Ortega A, Teichberg VI (1988) Isolation, immunochemical characterization and localization of the kainate subclass of glutamate receptor from chick cerebellum. EMBO J 7:26732679.

Gregor P, Mano I, Maoz I, McKeown M, Teichberg VI (1989) Molecular structure of the chick cerebellar kainate-binding subunit of a putative glutamate receptor. Nature 342:689-692.

Hampson DR, Wenthold RJ (1988) A kainate acid receptor from frog brain purified using domoic acid affinity chromatography. J Biol Chem 263:2500-2505.

Hampson DR, Wheaton KD, Dechesne CJ, Wenthold RJ (1989) Identification and characterization of the ligand binding subunit of a kainate receptor using monoclonal antibodies and peptide mapping. $\mathbf{J}$ Biol Chem 264:13329-13335.

Hollmann M, O'Shea-Greenfield A, Rogers SW, Heinemann S (1989) Cloning by functional expression of a member of the glutamate receptor family. Nature 342:643-648.

Hollmann M, Rogers SW, O'Shea-Greenfield A, Deneris ES, Hughes TE, Gasic GP, Heinemann S (1991) The glutamate receptor GluR 1: structure, function, and expression in the brain. Cold Spring Harbor Symp Quant Biol, in press.

Hudziak RM, Laski FA, RajBhandary UL, Sharp PA, Capecchi MR (1982) Establishment of mammalian cell lines containing multiple nonsense mutations and functional suppressor $t$ RNA genes. Cell 31 : 137-146.

Hughes TE, Carey RG, Victoria J, deBlas AL, Karten HJ (1989) Immunohistochemical localization of GABAa receptors in the retina of the primate Saimiri sciureus. Visual Neurosci 2:565-581.

Insel TR, Miller LP, Gelhard RE (1990) The ontogeny of exciatory amino acid receptors in the rat forebrain-I. $N$-methyl-D-aspartate and quisqualate receptors. Neuroscience 35:31-43.

Jacob MH, Lindstrom JM, Berg DD (1986) Surface and intracellular distribution of a putative neuronal nicotinic acetylcholine receptor. J Cell Biol 103:205-214.

Joels M, Urban IJA (1984a) Electrophysiological and pharmacological evidence in favour of amino acid neurotransmission in fimbria-fornix fibres innervation of the lateral septal complex of rats. Exp Brain Res $54: 455-462$

Joels M, Urban IJA (1984b) Amino acid neurotransmission between fimbria-fornix fibers and neurons in the lateral septum of the rat: a microiontophoretic study. Exp Neurol 84:126-139.

Jones DH, Matus AI (1974) Isolation of synaptic plasma membrane from brain by combined flotation-sedimentation density gradient centrifugation. Biochem Biophys Acta 356:276-287.
Ju G, Swanson LW (1989) Studies on the cellular architecture of the bed nuclei of the stria terminalis in the rat: I. Cytoarchitecture. J Comp Neurol 280:587-602.

Ju G, Swanson LW, Simerly RB (1989) Studies on the cellular architecture of the bed nuclei of the stria terminalis in the rat: II. Chemoarchitecture. J Comp Neurol 280:603-621

Keinanen K, Wisden W, Sommer B, Werner P, Herb A, Verdoorn TA Sakmann B, Seeberg PH (1990) A family of AMPA-selective glutamate receptors. Science 249:556-560.

Keyser KT, Hughes TE, Whiting PJ, Lindstrom JM, Karten HJ (1988) Cholinoceptive neurons in the retina of the chick: an immunohistochemical study of the nicotinic acetylcholine receptors. Visual Neurosci 1:349-366.

Kidd S, Baylies MK, Gasic GP, Young MW (1989) Structure and distribution of the Notch protein in developing Drosophila. Gene Dev 3:1113-1129.

Klein AU, Niederoest KH, Cuenod M, Streit P (1988) A kainate binding protein in pigeon cerebellum: purification and localization by monoclonal antibody. Neurosci Lett 95:359-364.

Krettek JE, Price JL (1978a) Amygdaloid projections to subcortical structures within the basal forebrain and brainstem in the rat and cat. J Comp Neurol 178:225-254.

Krettek JE, Price JL (1978b) A description of the amygdaloid complex in the rat and cat with observations on intra-amygdaloid axonal connections. J Comp Neurol 178:255-280.

McGeer EG (1989) Excitatory amino acids and Alzheimer's disease: idle thoughts on an exciting subject. Neurobiol Aging 10:614-618.

Miller LP, Johnson AE, Gelhard RE, Insel TR (1990) The ontogeny of excitatory amino acid receptors in the rat forebrain-II. Kainic acid receptors. Neuroscience 35:45-51.

Monaghan DT, Cotman CW (1982) The distribution of $\left[{ }^{3} \mathrm{H} \mid \mathrm{kainic}\right.$ acid binding sites in rat CNS as determined by autoradiography. Brain Res 252:91-100.

Monaghan DT, Holets VR, Toy DW, Cotman CW (1983) Anatomical distributions of four pharmacologically distinct [ $\left.{ }^{3} \mathrm{H}\right]-\mathrm{L}-$ glutamate binding sites. Nature 306:176-179.

Mori N, Wada JA (1987) Bidirectional transfer between kindling induced by excitatory amino acids and electrical stimulation. Brain Res 425:45-48.

Nadler SV, Perry BW, Cotman CW (1978) Intraventricular kainic acid preferentially destroys hippocampal pyramidal cells. Nature 271:676677

Nitecka L; Tremblay E, Charton G, Bouillot JP, Berger ML, Ben-Ari Y (1984) Maturation of kainic acid seizure-brain damage syndrome in the rat. II. Histopathological sequelae. Neuroscience 13:1073-1094.

Olney JW (1990) Excitotoxic amino acids and neuropsychiatric disorders. Annu Rev Pharmacol Toxicol 30:47-71.

Sommer B, Keinanen K, Verdoorn TA, Wisden W, Burnashev N, Herb A, Kohler M, Takagi T, Sakman B, Seaburg PH (1990) Flip and flop: a cell specific functional switch in glutamate-operated channels of the CNS. Science 249:1580-1585.

Somogyi P, Eshhar N, Teichberg VI, Roberts JDB (1990) Subcellular localization of a putative kainate receptor in Bergmann glial cells using a monoclonal antibody in the chick and fish cerebellar cortex. Neuroscience 35:9-30.

Stevens C (1989) A finger on brain receptors. Nature 342:620-621.

Stevens DR, Cotman CW (1986) Excitatory amino acid antagonists depress transmission in hippocampal projections to the lateral septum. Brain Res 382:437-440.

Stollberg J, Berg DK (1987) Neuronal acetylcholine receptors: fate of surface and internal pools in cell culture. J Neurosci 7:1809-1815.

Swanson LW, Cowan WM (1979) The connections of the septal region in the rat. J Comp Neurol 186:621-656.

Swanson LW, Simmons DM, Whiting PJ, Lindstrom J (1987a) Immunohistochemical localization of neuronal nicotinic acetylcholine receptors in the rodent central nervous system. J Neurosci 7:33343342.

Swanson LW, Kohler C, Bjorklund A (1987b) The limbic region. I: The septohippocampal system. In: Handbook of chemical neuroanatomy, Vol 5, Integrated systems of the CNS, Pt I (Bjorklund A, Hokfelt T, Swanson LW, eds), pp 125-277. New York: Elsevier.

Unnerstall JR, Wamsley JK (1983) Autoradiographic localization of high-affinity $\left[{ }^{3} \mathrm{H}\right]$ kainic acid binding sites in the rat forebrain. Eur $\mathbf{J}$ Pharmacol 86:361-371.

Wada E, Wada K, Boulter J, Deneris E, Heinemann S, Patrick J, Swan- 
son LW (1989) Distribution of alpha , alpha $_{3}$, alpha , and beta $_{2}$ neuronal nicotinic receptor subunit mRNAs in the central nervous system: a hybridization histochemical study in the rat. J Comp Neurol 284:314-335.

Wada K, Dechesne CJ, Shimasaki S, King RG, Kusano K, Buonanno A, Hampson DR, Banner C, Wenthold RJ, Nakatani Y (1989) Se- quence and expression of a frog brain complementary DNA encoding a kainate-binding protein. Nature 342:684-689.

Wigler M, Pellicer A, Silverstein S, Axel R (1978) Biochemical transfer of single copy eucaryotic genes using total cellular DNA as donor. Cell 14:725-731. 